\title{
Regulation of the levels of Smad1 and Smad5 in MC3T3-E1 cells by Icariine in vitro
}

\author{
HUIFANG ZHOU ${ }^{1,2^{*}}$, SHUO WANG $^{3,4^{*}}$, YUAN XUE $^{3}$ and NIANKE SHI ${ }^{1}$ \\ ${ }^{1}$ Department of Operative Surgery, Tianjin Medical University, Tianjin 300070; ${ }^{2}$ Department of Anesthesia, Xiqing Hospital, \\ Tianjin 300000; ${ }^{3}$ Department of Orthopaedics Surgery, Tianjin Medical University General Hospital, Tianjin 300052; \\ ${ }^{4}$ Department of Orthopaedics Surgery, the No. 464 Hospital of People's Liberation Army, Tianjin 300381, P.R. China
}

Received December 30, 2012; Accepted November 4, 2013

DOI: $10.3892 / \mathrm{mmr} .2013 .1837$

\begin{abstract}
The purpose of this study was to investigate the role of Icariine on the expression of Smadl and Smad5 mRNA and protein levels in MC3T3-E1 cells in vitro. MC3T3-E1 cells were cultured in the presence of different concentrations of Icariine $(0,10,40$ and $80 \mathrm{ng} / \mathrm{ml})$. Smad1 and Smad5 mRNA levels were detected by reverse transcription-polymerase chain reaction (RT-PCR) and the expression of proteins was determined by western blotting, immunohistochemistry staining and immunofluorescence. Smad1 and Smad5 mRNA levels continuously increased in 10,40 and $80 \mathrm{ng} / \mathrm{ml}$ of Icariine with time and the differences indicated statistical significance. Western blot analysis demonstrated that the Smad1 and Smad5 protein levels in the 10, 40 and $80 \mathrm{ng} / \mathrm{ml}$ groups were higher compared with the $0 \mathrm{ng} / \mathrm{ml}$ group at 24,48 and $72 \mathrm{~h}$, and the difference was statistically significant. Immunohistochemistry staining and immunofluorescence showed that the expression of the Smad1 and Smad5 proteins was higher in the cytoplasm and nuclei in the 10, 40 and $80 \mathrm{ng} / \mathrm{ml}$ groups compared with the $0 \mathrm{ng} / \mathrm{ml}$ group. Icariine has a direct stimulatory function on the differentiation of MC3T3-E1 osteoblastic cells in vitro, which may be mediated by increasing the production of Smad1 and Smad5 in osteoblasts.
\end{abstract}

\section{Introduction}

Due to the various drawbacks of cytokine and hormone therapy, traditional Chinese medicine was developed for adjusting the proliferation and the differentiation of osteoblasts, and has been employed as an important strategy in orthopaedic clinics and basic research. Numerous studies demonstrate that the most important cytokines affecting the proliferation, differentiation

Correspondence to: Dr Yuan Xue, Department of Orthopaedics Surgery, Tianjin Medical University General Hospital, 154 Anshan Road, Tianjin 300052, P.R. China

E-mail: xueyuan@medmail.com.cn

*Contributed equally

Key words: Icariine, osteoblasts, Smads, signal transduction and function of osteoblasts are transforming growth factor- $\beta$ (TGF- $\beta$ ) and bone morphogenetic proteins (BMPs). The intracellular mediators of TGF- $\beta$ are named Smads. Smad 2 and Smad3 have been demonstrated to stimulate the proliferation of osteoblasts and inhibit the differentiation of osteoblasts $(1,2)$. The intracellular mediators of BMP-2, Smad1 and Smad5, have been demonstrated to stimulate the differentiation of osteoblasts and expression of osteogenic-specific genes, including osteocalcin, collagen type I and bone salivary protein (3).

Icariine, the main active flavonoid glucoside isolated from Epimedium pubescens, is used as a tonic (meaning health promotion in traditional Chinese medicine) $(4,5)$. Icariine has been reported to be a potent enhancer of bone healing (6) and its extract is able to reduce the occurrence of osteoporosis, not only in experimental models $(6,7)$, but also in clinical studies (8). Icariine is able to promote the proliferation, differentiation and synthesis of type I collagen in osteoblasts in vitro (9-11) and treat osteoporosis by reducing bone loss in ovarian castrated rats in vivo (7,9-11). Increasing Smad4 levels in osteoblasts and promoting the secretion of BMP2 in osteoblasts may occur by the following mechanism $(9,11)$. Smad1 and Smad5 (R-Smads) are the downstream transcription factors, which may be activated and phosphorylated by the heterotetrameric serine/ threonine kinase receptors of BMP-2. The phosphorylated Smad1 and Smad5 form a complex with a Smad4 (Co-Smad), to translocate into the nucleus, activating the transcription factors of Cbfa1/Runx2. Transmission of BMP2 in osteoblasts was completed through receptor regulated Smad1 and Smad5 (R-smads) and common-mediator Smad (Co-smad; $3,12,13)$. However, recent literature demonstrated that BMP2 is only able to increase the amount of Smad1 and Smad5 in osteoblasts and not Smad4 levels $(3,12)$. By contrast, Smad4 is able to promote the differentiation of osteoblasts by stimulating the Wnt signaling pathway (14-16). The aim of this study was to explore the effect of Icariine on increasing the Smad1 and Smad5 mRNA levels in osteoblasts and on stimulating osteoblast differentiation.

\section{Materials and methods}

Materials. i) Icariine; 4H-1-Benzopyran-4-one,3-[(6-deoxy - $\alpha$-L-mannopyranosyl)oxy]-7-(beta-D-glucopyranosyl oxy)5-hydroxy-2-(4-methoxyphenyl)-8-(3-methyl-2-butenyl); for- 
mula, $\mathrm{C}_{33} \mathrm{H}_{40} \mathrm{O}_{15}$; was purchased from the National Institute for the Control of Pharmaceutical and Biological Products (NICPBP; national drug control product batch no. 0737 200111); ii) MC3T3-El cell lines were obtained from the Chinese Academy of Medical Sciences Cell Center; iii) TRIzol reagent (Invitrogen Life Technologies, Carlsbad, CA, USA), M-MLV (Solarbio Co., Beijing, China), Taq enzyme (Takara Bio, Inc., Shiga, Japan), RIPA lysis buffer (sc-24948; Santa Cruz Biotechnology, Inc., Santa Cruz, CA, USA); SDS-PAGE gel preparation kit (AR0138; Boshide Co., Wuhan, China), western blot chemiluminescence kit (Pierce Biotechnology, Inc., Rockford, IL, USA), bovine serum albumin (Roche Diagnostics GmbH, Mannheim, Germany), DAB chromogenic (TBD550; Tianjin Haoyang Co., Tianjin, China). Primary antibody $\beta$-actin (sc-47778), Smadl (sc-7965), Smad5 (sc-26418), secondary antibody IgG-HRP (sc-2005) and the donkey anti-goat IgG-HRP (sc-2020) were purchased from Santa Cruz Biotechnology, Inc.

\section{Methods}

Culture. MC3T3-El cells were cultured in DMEM high sugar medium supplemented with $10 \%$ fetal bovine serum (FBS) and $100 \mathrm{U} / \mathrm{ml}$ penicillin. The MC3T3-E1 cells, which were grown well, were seeded into twelve 6-well plates at a density of $3 \times 10^{5}$ cells/well. Icariine was added at concentrations ranging from $0-80 \mathrm{ng} / \mathrm{ml}$ to DMEM containing $10 \% \mathrm{FBS}$ on the first day. The cells were incubated successively for 24,48 and $72 \mathrm{~h}$. TRIzol reagent $(1 \mathrm{ml})$ was added to three wells of every 6-well plate and lactation protein extraction reagent was added to the other three wells. Then, the plates were frozen at $-80^{\circ} \mathrm{C}$ ready for reverse transcription polymerase chain reaction (RT-PCR) and western blot analysis. The cell density was $1 \times 10^{5}$ cells/well in an immunohistochemical test (cover glass preset in 6-well plates) and the cultivation method was the same as the former.

$R T-P C R$. The twelve frozen groups were incubated at room temperature for $5 \mathrm{~min}$ following thawing and then $0.2 \mathrm{ml}$ chloroform was added with oscillation for $15 \mathrm{sec}$. Following incubation at room temperature for $3 \mathrm{~min}$, twelve groups were centrifuged for $15 \mathrm{~min}$ at $13,326 \mathrm{x} \mathrm{g}$ at $4^{\circ} \mathrm{C}$ and then $500 \mu \mathrm{l}$ of supernatant was obtained joining $500 \mu \mathrm{l}$ isopropyl alcohol. Following incubation at room temperature for $10 \mathrm{~min}$ again, the liquid was disposed and then the supernatant joining $1 \mathrm{ml}$ $75 \%$ alcohol was eliminated. Finally, we centrifuged the liquid for $10 \mathrm{~min}$ at $13,326 \mathrm{x} \mathrm{g}$ at $4^{\circ} \mathrm{C}$ and eliminated the supernatant joining $40 \mu \mathrm{l}$ DEPC. In each group, $4 \mu \mathrm{l}$ oligo $(\mathrm{dT})_{16}(1 \mu \mathrm{g} / \mu \mathrm{l})$ was added into $10 \mu \mathrm{g}$ mRNA, then made up to $27 \mu \mathrm{l}$ with RNasefree water. The mixture was then exposed to $70^{\circ} \mathrm{C}$ for $5 \mathrm{~min}$ and subsequently immediately refrigerated for $2 \mathrm{~min}$. Following that, $8 \mu 1$ 5X M-MLV buffer, $2 \mu 1 \mathrm{dNTPs}(10 \mathrm{mM}), 1 \mu \mathrm{l}$ RNasin (40 U/ml) and $2 \mu 1 \mathrm{M}-\mathrm{MLV}(200 \mathrm{U} / \mathrm{ml})$ were mixed and blended at $42^{\circ} \mathrm{C}$. Following $60 \mathrm{~min}$, heating at $95^{\circ} \mathrm{C}$ for $5 \mathrm{~min}$ was used to finish the reaction. The specific primers of $\beta$-actin were: forward: 5'-CTAACAGAGAGAAGATGACG-3', reverse: 5'-AAGGAAGGCTGGAAGAGTG-3'. The specific primers of Smad1 were: forward: 5'-TGTGGCTTCCGTCTCTTG-3', reverse: 5'-CCAACACCCCACACAAAAG-3'. The specific primers of Smad5 were: forward: 5'-TACGCTGAGTGTCT TAGTG-3', reverse: 5'-ATGGTTGACTGACTGAGCC-3'. Amplification was conducted for 30 cycles, each of which was at $94^{\circ} \mathrm{C}$ for $5 \mathrm{~min}, 94^{\circ} \mathrm{C}$ for $30 \mathrm{sec}, 55^{\circ} \mathrm{C}$ for $30 \mathrm{sec}$ and $72^{\circ} \mathrm{C}$ for $60 \mathrm{sec}$ and then finally at $72^{\circ} \mathrm{C}$ for $7 \mathrm{~min}$ in a $25 \mu \mathrm{l}$ reaction system. The reaction mixture was constituted of $1 \mu \mathrm{l}$ of every primer, $2 \mu \mathrm{l} \mathrm{dNTP}, 0.5 \mu \mathrm{l}$ Taq enzymes and $1 \mu \mathrm{l}$ template. The products of PCR were analyzed with $15 \mathrm{~g} / \mathrm{l}$ agarose plate electrophoresis and the imaging system automatically analyzed the absorption value of every belt.

Western blotting. Using RIPA mammalian cell cracking liquid, the 12 groups were cracked and then centrifuged for $20 \mathrm{~min}$ at $4^{\circ} \mathrm{C}$ at $13,326 \mathrm{x} \mathrm{g}$ collecting $300 \mu \mathrm{l}$ of supernatant. Following that, equal amounts of proteins were mixed with the equal volumes of reducing $2 \mathrm{X}$ SDS sample buffer and boiled for $5 \mathrm{~min}$ at $100^{\circ} \mathrm{C}$. Protein samples were resolved on a $10 \%$ SDS-PAGE and then electroblotted on PVDF membranes. Following the electroblotting, non-specific binding was blocked with a $5 \%$ non-fat milk/PBS solution. The membrane was then incubated overnight with primary antibodies at $4^{\circ} \mathrm{C}$ followed by incubation with horseradish peroxidase (HRP) conjugated secondary antibodies for $1 \mathrm{~h}$ at room temperature. Proteins were visualized using enhanced chemiluminescence as previously described (17).

Immunohistochemistry staining. Once the cells were cultured for $72 \mathrm{~h}$, the treated glass slides were fixed in $4 \%$ formaldehyde at $4^{\circ} \mathrm{C}$ for $10 \mathrm{~min}, 3 \% \mathrm{H}_{2} \mathrm{O}_{2}$ for $10 \mathrm{~min}, 0.3 \%$ Triton X-100 for $15 \mathrm{~min}$ and $250 \mu \mathrm{l} 0.1 \%$ bovine serum albumin (BSA) at room temperature for $20 \mathrm{~min}$. Smad1 and Smad5-conjugated goat anti-mouse primary antibody $(250 \mu \mathrm{l})$ was applied at $4^{\circ} \mathrm{C}$ overnight, $250 \mu \mathrm{l}$ rabbit anti-goat biotinylated secondary antibodies were applied at $37^{\circ} \mathrm{C}$ for $30 \mathrm{~min}$, SABC was applied for $30 \mathrm{~min}$, then DAB was used for $10 \mathrm{~min}$. The cell nuclei were counterstained with hematoxylin. Immunostained cells were examined under an Olympus IX70 immunofluorescence microscope (Olympus, Tokyo, Japan).

Immunofluorescent staining. The cells, once cultured for $72 \mathrm{~h}$, were fixed in formaldehyde and blocked with $0.1 \%$ BSA for $30 \mathrm{~min}$. Cells were then stained with $250 \mu \mathrm{l} \mathrm{pSmad1-conju-}$ gated goat anti-mouse primary antibody at $4^{\circ} \mathrm{C}$ overnight and $250 \mu \mathrm{lgG}$ IgITC-conjugated donkey anti-goat secondary antibody at $37^{\circ} \mathrm{C}$ for $30 \mathrm{~min}$. The cell nuclei were counterstained with DAPI (4,6-diamidino-2-phenylindole dihydrochloride, $1 \mathrm{mM}$ ) for $1 \mathrm{~min}$. Immunostained cells were examined under an Olympus IX70 immunofluorescence microscope.

Statistical analysis. Results are expressed as the mean \pm standard deviation of these experiments and were statistically analyzed by one-way ANOVA. $\mathrm{P}<0.05$ was considered to indicate a statistically significant difference by Dunnett's test between the means of the control and test groups (SPSS, 16.0).

\section{Results}

The effect of Icariine on Smadl and Smad5 mRNA level in MC3T3-E1 cells. Once the MC3T3-E1 cells were cultured in the different concentrations of Icariine for 24, 48 and $72 \mathrm{~h}$, RT-PCR demonstrated that (Fig. 1; Table I): Smad 1 and Smad 5 genes continuously presented in the $10 \mathrm{ng} / \mathrm{ml}$ group with time; Smad 1 and 5 mRNA also have expression in the 40 and $80 \mathrm{ng} / \mathrm{ml}$ groups at 48 and $72 \mathrm{~h}$. In addition, in the $0 \mathrm{ng} / \mathrm{ml}$ group only Smad 1 mRNA was observed at $48 \mathrm{~h}$. There was statistical significance between the $0 \mathrm{ng} / \mathrm{ml}$ group and the 10 , 40 and $80 \mathrm{ng} / \mathrm{ml}$ groups (Dunnett's t-test, $\mathrm{P}<0.05$ ). 
Table I. Smad1 and Smad5 mRNA levels at various times under different concentrations of Icariin stimulation (x $\pm \mathrm{s}$ ).

\begin{tabular}{|c|c|c|c|c|c|c|}
\hline Time & Icariine $(\mathrm{ng} / \mathrm{ml})$ & $\mathrm{N}$ & Smad1:action & $\mathrm{F}$ & Smad5:action & $\mathrm{F}$ \\
\hline \multirow[t]{4}{*}{$24 \mathrm{~h}$} & 0 & 3 & $0.583 \pm 0.044$ & \multirow[t]{4}{*}{0.075} & $0.574 \pm 0.054$ & \multirow[t]{4}{*}{1.227} \\
\hline & 10 & 3 & $0.595 \pm 0.014$ & & $0.535 \pm 0.039$ & \\
\hline & 40 & 3 & $0.591 \pm 0.008$ & & $0.600 \pm 0.044$ & \\
\hline & 80 & 3 & $0.592 \pm 0.041$ & & $0.540 \pm 0.053$ & \\
\hline \multirow[t]{4}{*}{$48 \mathrm{~h}$} & 0 & 3 & $0.112 \pm 0.050$ & \multirow[t]{4}{*}{342.964} & 0.00 & \multirow[t]{4}{*}{395.542} \\
\hline & 10 & 3 & $0.687 \pm 0.011$ & & $0.533 \pm 0.024$ & \\
\hline & 40 & 3 & $0.781 \pm 0.018$ & & $0.547 \pm 0.337$ & \\
\hline & 80 & 3 & $0.748 \pm 0.022$ & & $0.489 \pm 0.014$ & \\
\hline \multirow[t]{4}{*}{$72 \mathrm{~h}$} & 0 & 3 & $0.213 \pm 0.049$ & \multirow[t]{4}{*}{144.120} & 0.00 & \multirow[t]{4}{*}{100.245} \\
\hline & 10 & 3 & $0.798 \pm 0.032$ & & $0.578 \pm 0.020$ & \\
\hline & 40 & 3 & $0.571 \pm 0.036$ & & $0.137 \pm 0.056$ & \\
\hline & 80 & 3 & $0.653 \pm 0.021$ & & $0.264 \pm 0.061$ & \\
\hline
\end{tabular}

24h: $>>0.05 .48 \mathrm{~h}$ : Smad1, $\mathrm{P}<0.05 ; \mathrm{Smad} 5, \mathrm{P}<0.05 .72 \mathrm{~h}$ : Smad1, $\mathrm{P}<0.05$; Smad5, $\mathrm{P}<0.05$. $\mathrm{x}$, mean; s, standard deviation.

Table II. Smad1 and Smad5 protein levels at various times under different concentrations of Icariin stimulation $(x \pm s)$.

\begin{tabular}{|c|c|c|c|c|c|c|}
\hline Time & Icariine (ng/ml) & $\mathrm{N}$ & Smad1:action & $\mathrm{F}$ & Smad5:action & $\mathrm{F}$ \\
\hline \multirow[t]{4}{*}{$24 \mathrm{~h}$} & 0 & 3 & 0.00 & \multirow[t]{4}{*}{123.165} & 0.00 & \multirow[t]{4}{*}{-} \\
\hline & 10 & 3 & $2.542 \pm 0.126$ & & 0.00 & \\
\hline & 40 & 3 & $2.669 \pm 0.148$ & & 0.00 & \\
\hline & 80 & 3 & $2.724 \pm 0.365$ & & 0.00 & \\
\hline \multirow[t]{4}{*}{$48 \mathrm{~h}$} & 0 & 3 & 0.00 & \multirow{4}{*}{233.905} & 0.00 & \\
\hline & 10 & 3 & $1.254 \pm 0.089$ & & $1.541 \pm 0.291$ & 31.866 \\
\hline & 40 & 3 & $1.363 \pm 0.095$ & & $1.675 \pm 0.308$ & \\
\hline & 80 & 3 & $0.924 \pm 0.052$ & & $1.218 \pm 0.199$ & \\
\hline \multirow[t]{4}{*}{$72 \mathrm{~h}$} & 0 & 3 & $0.698 \pm 0.049$ & \multirow[t]{4}{*}{71.727} & 0.00 & \multirow[t]{4}{*}{31.472} \\
\hline & 10 & 3 & $1.548 \pm 0.029$ & & $1.260 \pm 0.197$ & \\
\hline & 40 & 3 & $1.468 \pm 0.106$ & & $1.199 \pm 0.213$ & \\
\hline & 80 & 3 & $1.476 \pm 0.111$ & & $1.149 \pm 0.233$ & \\
\hline
\end{tabular}

24h: Smad1, $\mathrm{P}<0.05 .48 \mathrm{~h}$ : Smad1, $\mathrm{P}<0.05$; Smad5, $\mathrm{P}<0.05$. 72h: Smad1, $\mathrm{P}<0.05$; Smad5, $\mathrm{P}<0.05$. $\mathrm{x}$, mean; $\mathrm{s}$, standard deviation.

Effect of Icariine on Smadl and Smad5 protein level in MC3T3-E1 cells

Western blot analysis. The effect of Icariine on Smad1 and Smad5 protein level was examined at the following Icariine concentrations of $0,10,40$ and $80 \mathrm{ng} / \mathrm{ml}$ in 24, 48 and $72 \mathrm{~h}$ of culture. Icariine was able to observably upregulate the expression of Smad1 and Smad5 proteins. In the present study, there was a significant difference observed between the treated cells and that of the control on Smad1 (Dunnett's t-test, $\mathrm{P}<0.05$ ). Smad5 was detected in the 10, 40 and $80 \mathrm{ng} / \mathrm{ml}$ groups, however not in the $0 \mathrm{ng} / \mathrm{ml}$ group (Fig. 2; Table II).

Immunohistochemical staining. When osteoblasts were cultured with Icariine for $72 \mathrm{~h}$, the Smad1 and 5 proteins were significantly increased in the cytoplasm and nucleus. The cytoplasm and nucleus appeared brown by DAB coloration, and the cytoplasm appeared brown in the BMP-2 group which was the positive control group (Fig. 3).

Immunofluorescence staining. When osteoblasts were cultured with Icariine for $72 \mathrm{~h}$, the pSmad1 protein of the cytoplasm and nucleus was significantly increased and there was evidence that Icariine was able to increase the pSmad1, 5 proteins of Smad1 and Smad5. There was no yellow-green fluorescence in the negative control, however, the yellow-green fluorescence increased significantly in the positive control (Fig. 4).

\section{Discussion}

Smad proteins are important signaling molecules of TGF- $\beta$ families, which are important in intracellular signal transduction pathways. Smad2 and Smad3 mainly participate in the 

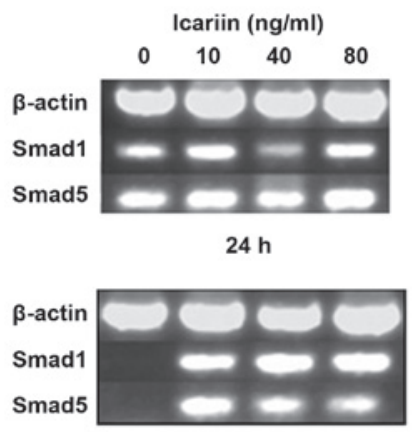

$48 \mathrm{~h}$

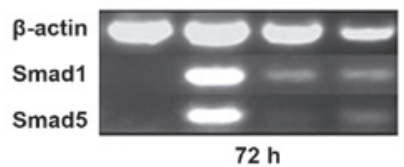

Figure 1. Smad1 and Smad5 mRNA expression in MC3T3-E1 cells using RT-PCR at different concentrations of Icariine at different times.
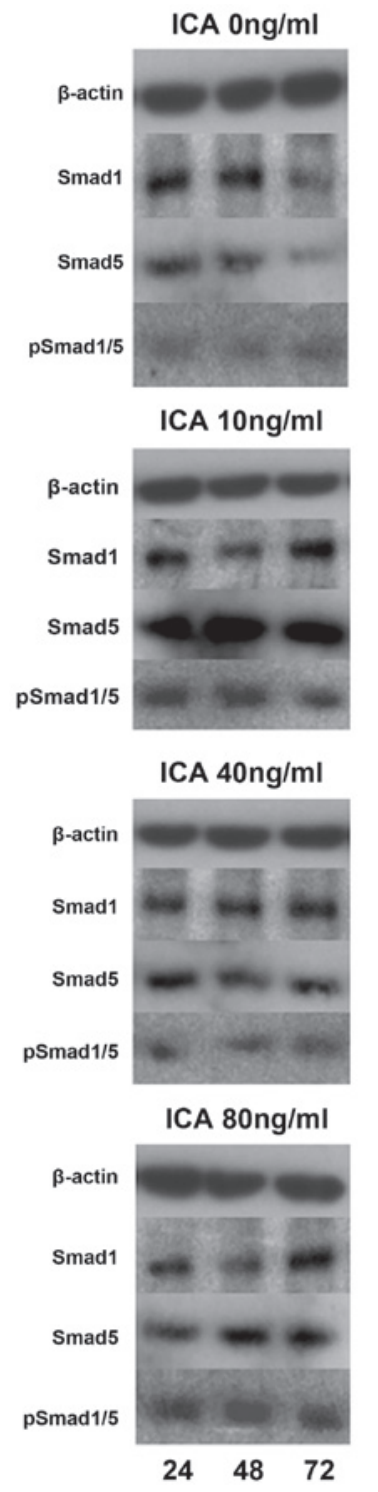

culture time (hours)

Figure 2. Smad1 and Smad5 protein expression in MC3T3-E1 cells using western blotting at different concentrations of Icariine at different times.

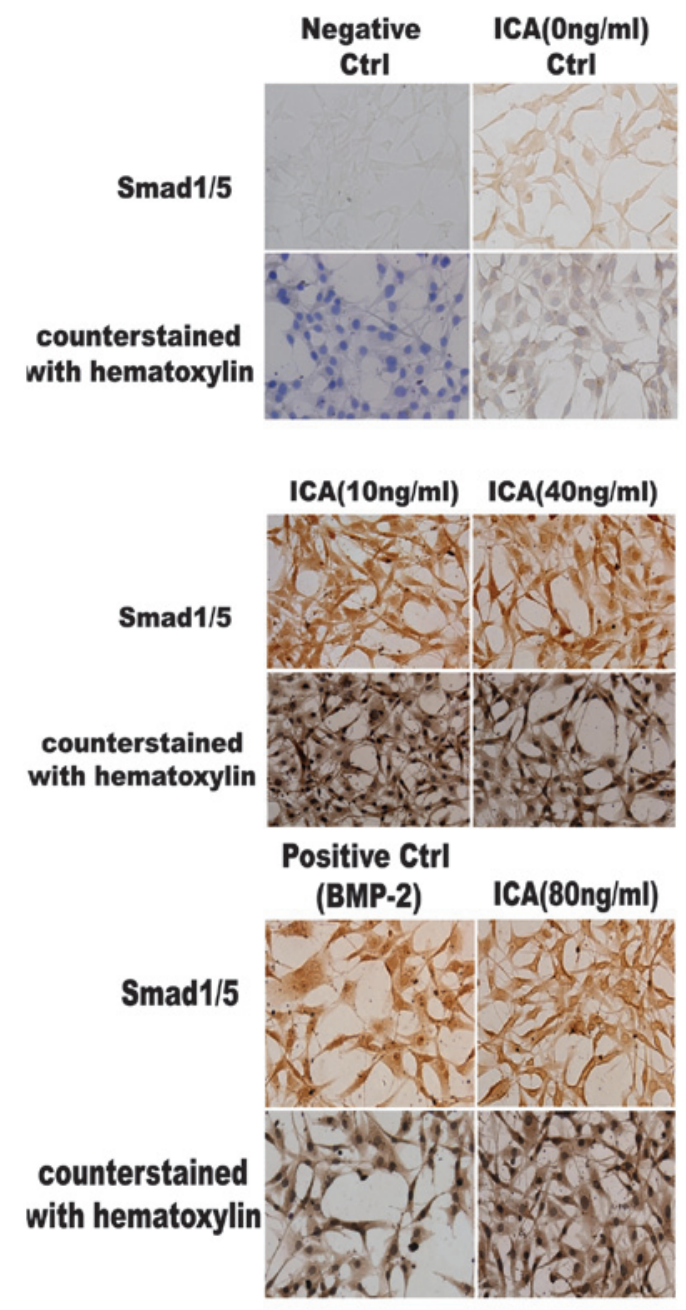

Figure 3. The immunohistochemical staining result. Ctrl, control; ICA, Icariine; BMP, bone morphogenetic protein.
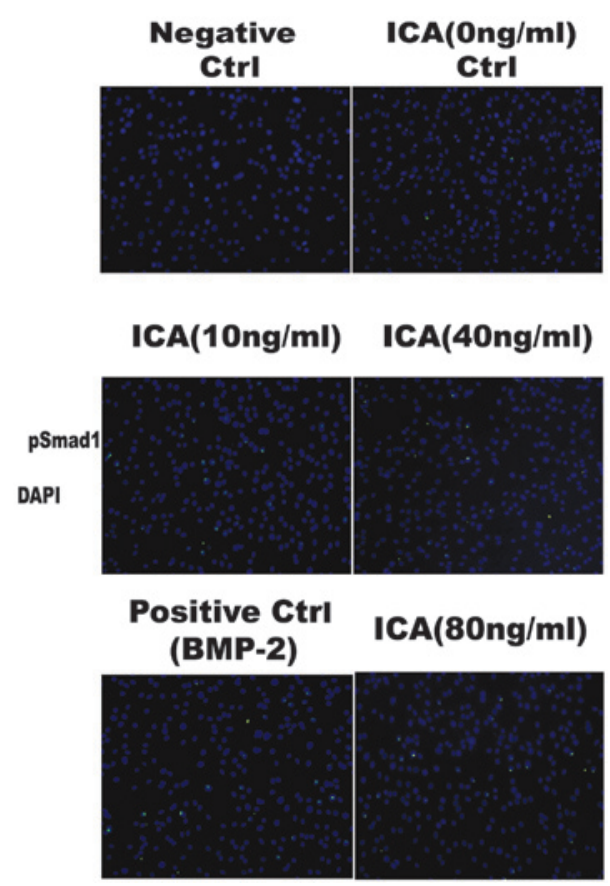

Figure 4. The immunofluorescent staining result. DAPI, 6-diamidino2-phenylindole dihydrochloride; ctrl, control; ICA, Icariine; pSMAD1, phosphorylated Smad1; BMP, bone morphogenetic protein. 
proliferation of osteoblasts as a downstream signal of TGF- $\beta$, and Smadl and Smad5 may participate in promoting the stimulation of BMP-2 $(3,16)$. Co-Smad4 and the R-Smads are able to form a transcription complex, which interacts with intranuclear transcription factors (Cbf $\alpha 1)$ that adjust the expression of differentiation products during different periods of osteoblast differentiation (12). I-Smads (Smad6,7) are negative control Smads which signal by interfering with the phosphorylation of $\mathrm{R}$-Smads or competitively inhibit the formation of R-Smad and Co-Smad oligomers (16).

In vitro studies demonstrated that Icariine is able to increase the level of BMP-2 mRNA in osteoblasts (11) and increase the expression of Smad4 mRNA in the hFOB 1.19 human osteoblastic cell line (9). In vivo, Icariine is able to dose dependently increase the expression of Cbf $\alpha 1 \mathrm{mRNA}$ in ovarian castration rats (7). In the present study, Icariine was able to increase the expression of Smadl and Smad5 mRNA and protein, which suggests that Icariine is able to further stimulate the differentiation of osteoblasts. Following $24 \mathrm{~h}$ of culture, the Smad5 mRNA expression was detected, however Smad5 protein expression was not. The inconsistency of the time indicated that the Smad5 was regarded as the necessary synergistic signal of Smad1 downstream and the second level Smads signal system was formed by Smad1 and Smad5.

In addition, in the immunological detection, it was demonstrated that Icariine was capable of increasing Smad1 and Smad5 proteins. Meanwhile, it was significant that Smad1 and Smad5 proteins were detected not only in the cytoplasm, but also in the cell nucleus. This result indicated that Smadl and Smad5 proteins were translocated from the cytoplasm into the cell nucleus following treatment with Icariine. Therefore, Icariine promotes the expression of Smadl and Smad5 mRNA and protein, and results in the differentiation of osteoblasts.

Pharmacological studies confirm that, as part of flavonoid compounds, Icariine exhibits estrogen-like activity and is able to adjust osseous metabolism by activating estrogen receptors (ERs) $(10,14)$. Yamamoto et al demonstrated that the ER signaling pathway downregulated the production of BMPs in osteoblasts in in vitro studies (15). We concluded that Icariine is able to promote osteoblast differentiation by through the BMP-Smad pathway rather than ER channels.

The Wnt signaling and the BMP2-Smadl, 5 signaling pathway cross-talk in promoting committed differentiation of osteoblasts. Signal-cross regulation targets exist in the cytoplasm, including $\beta$-catenin and Smads, and also exist in nuclear transcription regulatory factors, including Cbf $\alpha 1$ and lymphoid enhancer factor/T cell. $(13,16)$. In future studies, we aim to further clarify the mechanisms of the effects of Icariine on osteoblasts through examining the effect of Icariine on the Wnt signaling pathway.

\section{Acknowledgements}

This study was supported by grants from the National Natural Science Foundation of China (no. 30772193, no. 30973024 and no. 30571876) and the Tianjin Science and Technology Commission Key Project (no. 07JCZDJC08000). The authors are grateful to Professor Wen-Zhi Zhang, Laboratory of Neural Cells, Tianjin Huanhu Hospital, (Hexi District, Tianjin, China) for the assistance with cell culture.

\section{References}

1. Knoll BI, McCarthy TL, Centrella M and Shin J: Strain-dependent control of transforming growth factor-beta function in osteoblasts in an in vitro model: biochemical events associated with distraction osteogenesis. Plast Reconstr Surg 116: 224-233, 2005.

2. Fagenholz PJ, Warren SM, Greenwald JA, Bouletreau PJ, Spector JA, Crisera FE and Longaker MT: Osteoblast gene expression is differentially regulated by TGF-beta isoforms. J Craniofac Surg 12: 183-190, 2001.

3. Cheng H, Jiang W, Phillips FM, et al: Osteogenic activity of the fourteen types of human bone morphogenetic proteins (BMPs). J Bone Joint Surg Am 85-A: 1544-1552, 2003.

4. Liu CR and Xu LX: Analysis of active ingredients of traditional Chinese herbal drug: Assay of icariin in Epimedium. Chin J Pharm Anal 4: 81-84, 1984

5. Yang ZZ: Clinical applications of Yinyanghuo. Z J Trad Clin Med 20: 478-480, 1985.

6. Qin L, Zhang G, Hung WY, Shi Y, Leung K, Yeung HY and Leung P: Phytoestrogen-rich herb formula "XLGB" prevents OVX-induced deterioration of musculoskeletal tissues at the hip in old rats. J Bone Miner Metab 23 (Suppl): 55-61, 2005.

7. Qian GF, Zhang XZ, Lu L, Wu X, Li S and Meng J: Regulation of Cbfa1 expression by total flavonoids of Herba epimedii. Endocr J 53: 87-94, 2006.

8. Xie F, Wu CF, Lai WP, et al: The osteoprotective effect of Herba epimedii (HEP) extract in vivo and in vitro. Evid Based Complement Alternat Med 2: 353-361, 2005.

9. Liang W, Lin M, Li X, et al: Icariin promotes bone formation via the BMP-2/Smad4 signal transduction pathway in the hFOB 1.19 human osteoblastic cell line. Int J Mol Med 30: 889-895, 2012.

10. Shen P, Guo BL, Gong Y, Hong DY, Hong Y and Yong EL: Taxonomic, genetic, chemical and estrogenic characteristics of Epimedium species. Phytochemistry 68: 1448-1458, 2007.

11. Yin XX, Chen ZQ, Liu ZJ, Ma QJ and Dang GT: Icariine stimulates proliferation and differentiation of human osteoblasts by increasing production of bone morphogenetic protein 2 . Chin Med J (Engl) 120: 204-210, 2007.

12. Ghosh-Choudhury N, Singha PK, Woodruff K, St Clair P, Bsoul S, Werner SL and Choudhury GG: Concerted action of Smad and CREB-binding protein regulates bone morphogenetic protein-2-stimulated osteoblastic colony-stimulating factor-1 expression. J Biol Chem 281: 20160-20170, 2006.

13. Nakashima A, Katagiri T and Tamura M: Cross-talk between Wnt and bone morphogenetic protein 2 (BMP-2) signaling in differentiation pathway of C2C12 myoblasts. J Biol Chem 280: 37660-37668, 2005.

14. Liu J and Lou YJ: Determination of icariin and metabolites in rat serum by capillary zone electrophoresis: rat pharmacokinetic studies after administration of icariin. J Pharm Biomed Anal 36: 365-370, 2004.

15. Yamamoto T, Saatcioglu F and Matsuda T: Cross-talk between bone morphogenic proteins and estrogen receptor signaling. Endocrinology 143: 2635-2642, 2002.

16. Yavropoulou MP and Yovos JG: The role of the Wnt signaling pathway in osteoblast commitment and differentiation. Hormones (Athens) 6: 279-294, 2007.

17. Tian YC, Chen YC, Hung CC, Chang CT, Wu MS, Phillips AO and Yang CW: Leptospiral outer membrane protein induces extracellular matrix accumulation through a TGF-beta1/Smaddependent pathway. J Am Soc Nephrol 17: 2792-2798, 2006. 